\title{
DESIRE AND PLEASURE IN THE BRANDED REALITY SHOW AS A DISCURSIVE PSYCHOANALYSIS
}

\author{
Bambang Sukma Wijaya*
}

\begin{abstract}
ABSTRAK
Kajian mengenai branded reality show masih sangat terbatas, terutama dalam perspektif psikoanalisis wacana. Padahal, fenomena reality show saat ini sedang berkembang di jagat media pertelevisian, sehingga merek-merek pun tak tinggal diam untuk secara kreatifmenciptakan program sejenis. Tulisan ini bertujuan menganalisis hasrat dan pleasure kesuksesan yang dihadirkan dan disingkapkan oleh wacana branded reality show 'Diplomat Success Challenge' di sebuah saluran televisi nasional. Menggunakan metode psikoanalisis wacana dalam perspektif Lacanian, penulis menemukan bahwa peserta dalam program 'Diplomat Success Challenge' melihat kompetitor (peserta lain) sebagai other dalam fase cerminal yang merupakan objek hasratnya dalam memiliki pleasure kesuksesan, sementara pemirsa atau penonton menjadikan peserta yang muncul dalam tayangan acara sebagai cermin identifikasi hasrat dan pleasure kesuksesan dirinya. Terdapat dua kecenderungan gaya kepenontonan dalam merespon wacana dan mengidentikkan dirinya dengan subyek dalam tontonan. Di satu sisi pemirsa cenderung empatik dan figural, di sisi lain cenderung analitis, logis dan sistematis. Selain itu, hasrat dan pleasure kesuksesan dalam 'Diplomat Success Challenge' menjadi wacana kuat yang mengalienasi isu negatif terkait merek Diplomat sebagai produk rokok, di mana struktur ketidaksadaran 'menyembunyikan' realitas kesadaran mengenai wacana kenegatifan tersebut. Dengan demikian, politik realitas melalui wacana kesuksesan dalam branded reality show berhasil merasuk ke alam bawah sadar dan mengontrol kesadaran masyarakat.
\end{abstract}

Kata kunci: Hasrat dan Pleasure Kesuksesan, Branded Reality Show, 'Diplomat Success Challenge', Psikoanalisis Wacana, Kepenontonan

\begin{abstract}
The study of branded reality show is still very limited, especially in the perspective of discursive psychoanalysis. In fact, the phenomenon of reality show is currently growing in the television industry, so brands are inspired to create similar programs. This paper aims to analyze the desire and pleasure of success are presented and disclosed by branded reality show 'Diplomat Success Challenge' on a national TV channel in Indonesia. Using discursive psychoanalysis method in the Lacanian perspective, author found that participants in the 'Diplomat Success Challenge' saw competitors (other participants) as 'other' in imaginary phase which is the object of desire in having the pleasure of success, while the audience used the praticipants as reflection of their desire and pleasure of success. There are two tendencies of the spectatorship style in responding to the discourse. In one hand the audiences tend to be more emphatic and figural, while on the other hand they tend to be more logic and systematic. In addition, the desire and pleasure of success in the 'Diplomat Success Challenge' becomes a powerful discourse that alienated negative issues related to the Diplomat as a tobacco product brand. Thus, the politics of reality through a discourse of
\end{abstract}

\footnotetext{
* Brand scientist, strategist, and culturalist at the Department of Communication Science, Bakrie University
} 
success in the branded reality show has successfully infiltrated into the subconscious and control the public consciousness.

Keywords: Desire and Pleasure of Success, Branded Reality Show, 'Diplomat Success Challenge', Discursive Psychoanalysis, Spectatorship

\section{INTRODUCTION}

'Diplomat Success Challenge' ('DSC') is a program to search for reliable aspiring entrepreneurs with the most brilliant business idea (Wismilak-diplomat, 2013). In this program, the participants are required to submit a proposal for a business idea and are then selected by a selection committee. Those whose proposals get through the selection will take part in the next stage. Two challengers (designation for participants) with the best proposal and grade from each region will meet in the grand final in Jakarta. The 2013 'DSC' provides a total prize of business capital of one billion rupiahs.

As a branded reality show, 'DSC' collaborates with a national television station to broadcast every stage of participant selection in each region up to the grand final in Jakarta as broadcasted on December 14th, 2013. This program always displays the tension expression of the participants when dealing with any challenges and presentation to the juries, as well as the comments from other participants, thus contributing to producing a fierce competition reality show which is a very tight for being the winner. Similarly, comments from the juries and the host or presenter are also very dramatic.

Branded reality show is actually almost identical to another reality show that is usually sponsored by one or several brands (brand sponsorship). What distinguishes it is the inclusion of a single brand sponsor name in the name of its program. Such an integration does not only manifest in the program name, but also in the content and implementation of its program or production. The media acts as production partner and publisher, while idea and concept of the program come from the brand holder/owner, not the media, so that the program is more exclusive as commonly found in the product advertising by a brand holder, but this program is designed as a reality show. This is what distinguishes it from sponsorship of ordinary reality show in which the media serves as program owner and organizer while product brand or company serves only as supporting partner (sponsor, neither the producer nor the owner of idea or concept), both in the form of brand placement or product placement, commercials (in the ad spots), and built-in program branding (the story behind or during the program that involves participants and the supporting brand as the story content).

Thus, it can be said that branded reality show is a television reality show program made by a company as the brand owner in cooperation with the media for the purpose of marketing communication and branding by integrating the brand message to the name and content of the program. In the perspective of branding or brand communication, branded reality show acts as one form of branded entertainments, i.e. brand communication made by intensely involving a product in the entertainment show, funded by the marketer and produced in collaboration with an entertainment producer, thus producing an entertainment content with a show displaying quite prominent products or brands (Russell, 2007). Lehu (2007) suggests some other forms of branded entertainment including branded movie, branded song, branded novel, branded games, branded music concert, and others. As described above, the branded entertainment's hallmarks which set it apart from usual brand sponsorship are (1) the integration of brand content and program content, (2) program organizer or producer is the brand itself in cooperation with the media (3) the media serves as supporting partner and publisher/ program reporter.

Like the term of reality show that has many name alternatives such as "reality TV" (Reiss \& Wiltz, 2004; Bennett, 2005; Hill, 2005; Kjus, 
2009; Bonsu, et al., 2010), "TV show" (Brioux, 2008) or "reality TV show" (Papacharissi \& Mendelson, 2007), the term of branded reality show is also sometimes called "branded TV show". From the literature study results, a specific study and review of branded reality show so far has not been found in the official scientific publication, either in the perspective of communication, media and cultural studies, or marketing management and branding.

However, a lot of studies on product or brand placement have been done (La Ferle \& Edwards, 2006; Lehu, 2007), as well as those on sponsorship activities for the purpose of marketing and branding (Cornwell, et al., 2006). Another study that is close to the concept of branded reality show is advertainment (Deery, 2004; Russell, 2007). Advertainment refers to promotion practices that integrate brand communication into the content of entertainment products (Russell, 2007). Russell splits three categories of advertainment according to its degree of integration, including product placement (more portion of entertainment content), product integration (balanced portions of entertainment and brand contents) and branded entertainment (more portion of brand content). Thus, branded reality show is one of advertainment forms in the category of branded entertainment. Deery (2004) argues that advertainment is a result of competition in the media industry, which later creates a new pattern of cooperation relationship between advertiser and media.

In Indonesia, branded reality show has not shown a phenomenal growth. Indonesian audience only knows the format of branded variety show (not reality show) such as 'Gebyar BCA'. The blocking time programs such as 'Kemilau Mandiri Fiesta' or 'BRI di Hati' from banking brands are also classified as branded variety shows which are incidental or sporadic because they are only occasionally aired during the grand prize announcement by inviting loyal customers. These blocking time programs are not different from ordinary corporate gathering events, only modified with TV broadcasting.

However, at the end of the $90 \mathrm{~s}$ decade, a film product brand 'Kodak' from the United States launched its branded reality show in the form of travel quiz titled 'Kodak Fiesta', but only lasted a few episodes. In addition to 'DSC', Indonesian viewers are currently presented with another two branded reality show programs namely 'Hypermart Show' (hosted by Hypermart brand) which is aired every Saturday and 'Jams Session' which is organized by Jamsostek brand. Apart from these two programs, another TV show programs are only in the form of branded entertainment (non-reality) like the play 'Segelas Cerita Keluarga Kusuma' [A Cup of Story about Kusuma's Family] (a fragment series inspired by the message of a tea brand 'Sari Wangi' about a warm family communication with its tagline, mari bicara [let's talk]), and almost all TV stations broadcast a variety of programs with brand sponsorship, brand placement and built-in program branding.

As described above, the branded reality show studies are still very limited, especially in the perspective of psychoanalysis to examine desire and pleasure. Apart from Deery's study (2004) which views reality shows as a form of advertainment, those which specifically concern about the psychoanalysis of branded reality show so far have not been found. Even in academic studies, the use of the term 'branded reality show' itself so far also has not been found through the literature study results. On the other hand, the studies of reality show (non-branded) mostly come from the perspective of business and management (Bonsu, et al., 2010), politics (Bennett, 2005), psychology (Reiss \& Wiltz, 2004), communication (Nabi, 2007; Papacharissi \& Mendelson, 2007; Kjus, 2009), and pop culture (Hill, 2005; Aslama \& Pantti, 2006; Brioux, 2008). As a consequence, branded reality show studies from the perspective of psychoanalysis become significant because, in addition to implicating multiple production 
of desire and pleasure stimuli for the audience (consumers), they also have the potential to bring the twin acculturation between media and corporate in an intercourse (Deery, 2004) which tends to be exploitative, even destructive.

Therefore, this study was specifically aimed to understand how the discourse of branded reality show 'DSC' reveals the desire and pleasure of success, in the context of both spectacle and spectator, by trying to explore and dialogue various existing references with the study object reality of branded reality show from the perspective of psychoanalysis of Lacanian discourse. Lacan (1997:2006) claims that desire and pleasure are living in unconsciousness, actually structured like language, so they can be read and studied more deeply in the context of media (Ott, 2004) as a text or discourse. To conduct this study, several episodes of 'DSC' branded reality show (MetroTV, 2013) were watched by downloading them on YouTube, and then observing the discursive texts of the program which displayed narration and comments from both participants and juries.

Meanwhile, to understand the spectators' (viewers) desire and pleasure of success in relation to the spectacle of branded reality show, this study observed the reaction of the viewers while watching together the grand final on a national television channel on December 14, 2013. Besides making notes and recording their responses, the author also observed their expressions and body languages. Certain events and spontaneous utterances they made were then quoted and analyzed according to the context of spectatorship.

\section{DESIRE, BRAND, AND TELEVISION (MEDIA)}

Discussing about desire and pleasure cannot be separated from the two leading psychoanalysis theorists, i.e. Sigmund Freud and Jacques Lacan. Freud believes that human life is controlled by the need to repress the tendency of their intrinsic desire fulfillment and direct it so that the meaning of the delayed fulfillment can be more socially acceptable (Eagleton, 1983 in Flitterman-Lewis, 2005). The repression against this tendency of desire fulfillment is basically called pleasure principle, while the social acceptance of the meaning of this delayed desire fulfillment is called reality principle.

This desire fulfillment principle is also a branding principle. Kornberger (2010) argues that unlike products that are made to meet human needs, brand is designed to produce desire. When desire arises, product will be the answer. In this context, the product also metamorphoses, making it no longer a need footing but a desire escape produced by the brand through communication and branding activities.

The history of branding cannot be separated from the contribution of Freud's psychoanalysis. It was Edward Bernays, Freud's nephew, who changed the constellation of communication as a marketing tool from the paradigm of advertising to the paradigm of branding. In the 1920s, most of products are sold by highlighting their functions to persuade potential customers. Advertising was full of product information to ensure the 'strength' of the products. Bernays then changed this way. The focus of communication is no longer like conventional advertising which 'idolizes' the superiority of product functionality, but how to associate product with community's unconscious desire. There is a shift from the orientation of need fulfillment into the stimulation of desire. If the need fulfillment stops on the products or services offered, then the desire becomes an appetizer which, according to Zizek (1997), will never have a 'dessert' because a desire will produce another desires without ending.

In the pleasure principle, this condition is the repression against the desire fulfillment that creates pleasure. Therefore, desire is always associated with pleasure, actively produced by human in the unconscious repression. Meanwhile, the unconsciousness, according to Freud, is the place where unfulfilled desires are inherited. This 
means, behind human consciousness is actually where the human's everyday social interactions lives dynamically, fighting actively against desire which is logically and rationally unacceptable. The life behind this consciousness, by Freud, is called 'the other stage' where human's 'psychic drama' is being performed (Flitterman-Lewis, 2005).

Thus, Freud argues that human desire or unconscious life is under the control of ego or consciousness, which is only 'off' or released in the form of dream. According to Freud, dream is a special line towards unconsciousness (Lacan, 2006). This is because dream is a symbolic fulfillment of desires and expectations under unconsciousness (Ragland, 2000). If it comes to the surface of consciousness, then the repressed desire will be 'other' for the consciousness, strange and illogical. Freud considers it as the victory of ego (consciousness) over id (unconsciousness) when the ego controls the id (Fink, 1996). Ego which consists of self-identity and rational selfhood will always anticipate the emergence of instinctual $i d$ and replace it when emerging to surface of consciousness.

This thesis is fundamentally contradicted by Jacques Lacan, a French philosopher. Lacan argues on the contrary, i.e. unconsciousness (id -the repressed desire) is the one that controls human consciousness (ego) since unconsciousness is indeed structured like a language (Lacan, 1997). We know the existence of unconsciousness when it 'speaks' to us through the language of dreams, neuroses, and joy. Lacan re-translates Freud's thought in the context of linguistics or language or text or discourse which has cultural implications (Alcorn, 1994) and later becomes the basis for theories of film and television psychoanalysis (Flitterman-Lewis, 2005) or media (Ott, 2004) in general.

Borrowing the Freud's concept of pre-oedipal and oedipal, Lacan analogizes Freud's concept concerning oral-anal-phallic phase with the realthe imaginary-the symbolic phase as shown in the following figure.
Figure 1

The Development of Desire in the Freudian and Lacanian Perspectives

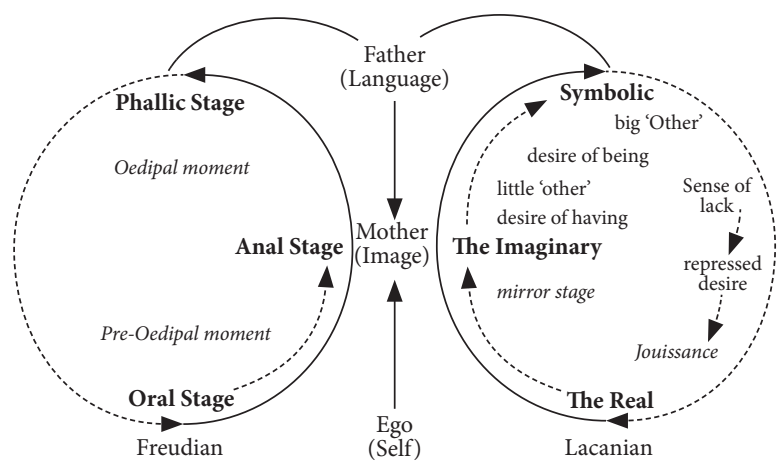

Source: Author's Analysis

The real phase is the ideal phase, i.e. a phase when subject is in an all-sufficient condition, all needs are met. This can be best described by a very comfortable life of a baby in the womb of his/her mother in which the two converge. In this phase, the subject (baby) has a perfect ego (self) whereby it cannot distinguish its self from its mother.

The baby then enters the imaginary phase in which it starts to realize that its self is separated and has its self-integrity which is different from its mother. It is likened to a child standing in front of a mirror and see a shadow which he/she thinks it is his/her self, whereas the shadow is another subject. That is why, this phase is also called the mirror stage. Mirror for a child is like mother for a baby. Here, there is a false in the process of self-identification by the subject (Lacan, 2006; Billig, 2006). The image or shadow which is reflected and identified by the subject him/her self is nothing but the desire of 'the other' over the subject's own self, thus resulting in alienation within the subject. In this phase, the other which is the subject's self-reflection is called the other with small 'o' (Kirshner, 2005). Not surprisingly, we tend to see our desires on other (people) desires, and see ourselves (identity) from other (people) images or shadows.

In the context of brand, the ideal shadow or image is displayed to reflect the consumers' illusive identity. Beauty, happiness, success, 
virility, generosity, and other billions of images and realities are constructed by brand to be a mirror that derails consumers' identity. Various discourse technologies and apparatuses are involved, for example, by using public figures or celebrities (Kjus, 2009) as well as ordinary people figures representing ordinary consumers through a media narration. In this constructive shadow or image of brand, as if consumers see and think that it is themselves. Thus, when using a product which is promoted by a brand, consumers feel the product is in accordance with and even a part of themselves, whereas, of course, all the displayed images are not the consumer image, but purely brand image (Wijaya, 2013).

This is also similar to the constructive image and reality displayed by television media. With its narrative and terrestrial audio-visual capability, television has the potential to massively produce desire stimuli. Not only that, television also produces social reality in the form of sophisticated symbols (Adi, 2006). Thus, what television shows is not only a spectacle stage, but at the same it is also a mirror which is 'believed' by audiences as a reality which represents 'themselves'. This attraction of reality (Papacharissi \& Mendelson, 2007) and image is packaged in the forms of either movie shows, entertainment programs like variety show, talk show, reality show, or in form of news which currently also tend to be narrative and constructive for trying to shape certain perception through the discourse technology of agenda setting. Audiences believe the truth displayed by the media as an actual reality (Brioux, 2008) whereas all of that is merely the media's constructive reality. Therefore, the intercourse between brand and media in constructing a reality creates the powerful hyperreality which potentially 'colonizes' the society's personal, social and cultural lives.

The next phase is the symbolic phase, i.e. a phase when the subject's existence is recognized by a language structure and the inclusion of the language structure into the subject itself through naming and statement. In this phase, the subject has the desire of having a full identity which is called ' $\mathrm{I}$ ' through language recognition. Consequently, the subject, inevitably, must be obedient to the rules of signification system in language space (Lacan, 1997). Language in the Lacanian perspective is like a father figure in the Freudian perspective, whose presence becomes a symbol of repression, but is always needed and desired.

Undeniably, brand language is the 'law' language of lifestyle and identity. In designing the 'law', a brand investigates and affirms its consumers' dreams and obsessions then weaves them into lifestyle trend and new identity through communication messages that must be obeyed by the consumer society on a large scale. Phrases like 'biar gaul' (to be up-to-date), 'biar ngetren' (to be trendy), 'biar moderen' (to be modern), 'biar ngga kuno atau jadul' (to be not out-ofdate), 'biar sehat' (to be healthy), 'biar cantik' (to be pretty), 'biar jadi bintang' (to be a star) and so on are discourses which deliberately campaigned by brand to 'regulate' consumers in order to follow the brand language. By following the brand language, by consuming products offered by the brand, then as if consumers get pleasure from the image which is constructed by the brand through those discourses. Although economically, socially and culturally repressed by the 'law' of brand language, consumers remain desiring it because, on this brand language, consumers find social recognition over 'their selves'.

This is barely indifferent from the 'law' of television media language. Through agenda setting, the audiences' desire traffic can be controlled and directed by the media for the benefit of (the group interests behind) media. Inevitably, any media language is the language of interest, either economic, political or other ideological interests (Bonsu, et al., 2010). When brand and media collaborate, then the produced 'language' will be the cross result of brand and media interests in regulating the desires of consumer audience-media's audience who also acts as a brand's consumer (Wijaya, 2011). In this case, the consumer audience's desire rests on the desire of having the pleasure from a reality which 
is jointly constructed by both brand and television media.

Another desire is the desire of being a whole subject, not splitting and without lack, loaded with fulfillment (Lacan, 2006; Ruti, 2010). This subject is 'the Other' with big ' $O$ '. The desire of being this big ' $\mathrm{O}$ ' means desiring back on the Real which has been disappeared since the mirrored splitting moment and at the time the contact with the language. This creates a sense of lack. Humans are actually controlled by various senses of loss and lack. Our life is like a search program for fulfilling something lacking. This existential lack, of course, will never be fulfilled and satisfied. In the Lacan language, it is likely impossible to return to the Real because it is impossible to 'return' into the mother's womb. That is why, the desire will always undergo repressed desire in the form of jouissance which is 'pleasure' resulting from repression (Fink, 1996).

In today's postmodern era which is full of hyperrealities, brand ceaselessly creates the big ' $\mathrm{O}$ ' and illusive jouissance through its powerful credo 'always understanding consumer's wants'. The consumer's wants and dreams of being (desire of being) are articulated into new languages that create image update or endless constructive reality. Not surprisingly, within a certain time, a brand always launches new campaign messages that provoke consumers' desire to always update and adapt to new constructive realities. Such a discourse technology called trend setting, and brand is often referred to as trend setter. The discourse on the pleasurable and endless brand trend is the big ' $\mathrm{O}$ ' of consumers, while the resulting 'pleasure' can be considered as brand jouissance.

Meanwhile, television media's jouissance, intertwines between agenda setting, actual reality and constructive image, manifests in the form of pleasurable narration. The audience is 'drugged,' trailing every narrative fabric to pursue the fulfillment of the desire of being the Real which, of course, will never be fulfilled. Narration has blinded repressive pain due to the 'law' of media language, and the consumer audience is swept away in the pursuit of that desire which is (actually) illusive. When brand comes to marry television media with all of its wealth of audiovisual image, consumer audience increasingly gets lost in the scent of wafted double-jouissance, making their desire multiplies in the pursuit of the big 'O'.

\section{THE PSYCHOANALYSIS OF BRANDED REALITY SHOW}

In his article entitled "Psychoanalysis, Film, and Television", Flitterman-Lewis (2005) discusses the film or cinema studies from the perspective of psychoanalysis to put forward the Christian Metz's theory about film spectatorship. Different from film studies in mass communication or sociological perspective that only analyzes viewers or film audience as public audience physically, or formalistic studies that assess the consciousness of audience in enjoying films from the artistic aspect only, the psychoanalytic approach on film media assesses the film spectatorship in relation to the distribution of desire, in a sense that enjoying film text equals to mobilizing fantasy or unconscious dream structure. Fantasy, as argued by Freud, is the fulfillment of a desire in the form of imaginary scene production by which the dreamer-subject acts as protagonist.

Thus, the psychoanalytical film theory emphasizes the 'production', whereby the audience produces desire, in the sense that when they are watching a film, they are actually dreaming of it. This is where the unconsciousness works and intertwines with 'various dreams' of a film. Jean-Louis Baudry (in FlittermanLewis, 1992: 158) suggests the elements of spectatorship which are engaged in the desire production machine and are 'responsible' for the unconsciousness as a cinematic apparatus, a complex and interconnected structure, including: (1) technical base (special effects created by film equipment such as camera, light, film, projector, 
etc.), (2) film projection condition (dark cinema room, fixed seats, large screen, and light beam from cinema projector), (3) the film itself as a 'text' (visual series, real space illusion, convincing impression creation of a reality), and (4) the 'mental machine' of spectatorship (including consciousness and unconsciousness perception and process prior to the consciousness).

However, the theories of film spectatorship as proposed Metz and Baudry become irrelevant when applied to television spectatorship (Flitterman-Lewis, 2005). In addition to production technical basis factor, the condition and circumstance when watching television are also different from watching film in cinema. Film (cinema) is watched in large format, silent audience, dark room with light beam projecting from behind the audience, while watching television has the opposite conditions: small screen, movable viewers/audience position, bright room without projector, and another important factor: television viewers know each other well and freely change TV channels so that the spectacle materials can change at any time. In this way, the viewers/audience control the television, while film (cinema) controls the audience. We come to the film (cinema), while television comes to us (our home) (Flitterman-Lewis, 2005). In addition, in case of 'text' or discourse, both film and television have different form and content. Similarly in the perspective of psychoanalysis, there are differences in the ways of presenting and understanding realities which are associated with POV (point-of-view) structure and reverse-shot. Furthermore, Flitterman-Lewis explains that:

Whether live or on tape, much of television -from news programs and talk shows to soap operas and situation comedies-creates the impression that we are watching events as they take place. Whatever the format, television's "immediate presence" invokes the illusion of a reality presented directly and expressly for the viewer (FlittermanLewis, 2005: 163).

Although claimed to represent reality, television is actually a powerful ideological tool that shapes our understanding of reality, thus changing the reality itself (Bonsu, et al., 2010). Therefore, reality depends on a variety of communication strategies like dramatization and exaggeration whose intention is, one of which, to attract and retain the viewers' attention (Bourdieu, 2001).

Reality has become the commodity of television, not only in the news and coverage of life (Bennett, 2005), but also in entertainment programs such as reality TV or reality show. Reality TV (show) produces sense of the real, delivered through the expectation of reality that is constructed by the TV itself (Bonsu, et al., 2010). Many studies indicate that a reality show in television exploits self-awareness between different genres to attract diverse viewers and exploit different markets (Aslama \& Pantti, 2006). This does not only combine the aesthetics of documentary with soap opera plots and game show competition styles (Coles, 2000), but it also provides a variety of nontraditional ways to build selfhood through various kinds of talk shows. The commodification and exploitation of reality in reality shows, eventually, will make the term 'reality' to be merely considered as 'accessory' and fiction.

In this way, the extent to which we judge the truth of the visual evidence that shown by reality show depends on how the television media represents the real participants and their stories in the reality show (Hill, 2005). Winston (1995) argues the claims of reality is something that is prevalent in reality show, but there is very limited investigation into the truth, the extent to which the quality of this reality. This is actually recognized by viewers. TV viewers or audiences are actually very aware of how the television shows the truth (reality) together (Brioux, 2008) and even they are talking about its format or editing technique that affects the level of 'reality' in reality show that they are watching. The stronger the allure of entertainment, the lower the level of reality. Hill (2005) claims that since the beginning of its presence, reality show has indeed been criticized on its 'behaviors' which are voyeuristic, cheap, 
and sensational, even metaphorical, e.g. drug addiction which is displayed in reality show, in relation to the effects of media on the viewers and, more broadly, on the society (related to moral, social and cultural values).

In fact, however, reality show remains one of the interesting spectacle objects for TV viewers (Nabi, 2007) with all its allure of entertaining reality (Papacharissi \& Mendelson, 2007). One reason why reality show becomes very powerful in the market is due to its allure for the young adult audiences (17-25 years old). Reality show is able to involve the audiences emotionally (Bonsu, et al., 2010). The results of research by Hill (2005) about the idea of learning in reality show also shows that some genres and formats of reality show provide informative benefit, entertainment, practical learning and social learning for the audiences. However, the astonishing one is the research by Reiss \& Wiltz (2004) which indicates that 'status' is the primary motivating force that drives the audiences' interest in the reality show on television. More and more people are statusoriented, making them more interested to watch reality show and showing their pleasure and enjoyment. The viewers/audiences of reality show are also more motivated by 'revenge', while the desire for revenge is closely related to the pleasure of competition.

Therefore, reality show, whatever the concept of 'reality' it carries, will be interesting to study, especially from the perspective of psychoanalysis which sees reality as a result of the desire repression to get pleasure on other realities. This is also similar to branded reality show in which the reality of brand (Grassl, 1999) intertwines with the reality of other subjects which are involved in the construction of branded reality show. Deery (2004) suggests some intercourse styles of brand (advertising) and entertainment in the form of reality show as follows: the commodification of reality and experience of consumers (where the consumer's brand-related experience becomes a reality show), the commodification of the view (in which objects in reality show are allowed/ recommended to further reveal themselves so that it becomes voyeuristic pleasure for viewers), and the product placement (placement of product/ brand on a reality show). La Ferle \& Edwards (2006) claims that product placement makes the appearance of brand in a program (show) is significant to create awareness and image of a brand, especially if the value of the brand is congruent with the program it sponsors, since synergistic sponsorship will provide important articulation in consumer memory (Cornwell, et al., 2006).

\section{THE DESIRE AND PLEASURE OF THE PARTICIPANTS' SUCCESS}

It was not easy for the participants of 'DSC' branded reality show to get to the grand final stage. First, they were required to submit business idea proposals whose feasibility was then assessed. The submitted proposals were selected through the first stage of selection which was divided into 4 (four) regions, i.e. Outer Region (overseasSingapore), West Region (Jakarta, Banten, West Java, and Sumatra), Central Region (Central Java, Yogyakarta and Kalimantan), and East Region (East Java, Sulawesi and Eastern Indonesia). There were 30 (thirty) proposals selected from each region for an audition. From the audition results of 30 proposals in each region, the 6 (six) best proposals were then selected for following the next stage of selection. After the six (6) finalists in each region were selected, the next stage was to select a local winner, starting from West Region, Central Region and then East Region in which the interval time for each selection was 4-5 days. Meanwhile, 6 finalists from Outer Region (Singapore) were divided into 3 groups (each consisting of 2 participants) who were then assigned to three different regions so that in each region, there were 8 finalists to fight for the two best winners. From here, two (2) winners from each region then stepped up to the Grand Final in Jakarta to fight for a business capital worth a total of IDR 1 billion. The assessment included the following criteria: originality, innovation, clarity of 
presentation, vision and business idea realization, business idea feasibility from both technical and marketing aspects, as well as the competitive value of the business idea in its realization (Wismilakdiplomat, 2013).

The participants of 'DSC' branded reality show were prospective entrepreneurs and smallmedium enterprise (SME) entrepreneurs who were developing or wish to develop their business. By participating in 'DSC' with a total business capital prize of IDR 1 billion, they were eager to win the prize and dreamed of becoming a successful entrepreneur. The tight and tense competition stages-juries pressure, competitive pressure, and self-pressure due to great expectation to wintriggered their adrenaline.

"We will see the extent to which you desire to be successful. An entrepreneur usually loves challenge, and we will challenge you here!" said Helmy Yahya, one of the juries when welcoming finalists in the Grand Final which was broadcasted in dramatic scenes. The camera panned some response expressions of the finalists standing upright with uniform executive-style suits. Some were tense, look flat, but some spontaneously clenched hands as if to say 'yess' with a bright face.

The aroma of competition has wafted from the early episodes of the program. One of the participants, a woman, in episode 2 said, "Here we can see who we are when looking at the knowledge and experience of fellow Challengers [designation for participants who escaped from the early stages] who are averagely excellent. I'm not so sure [to be the winner], but I'm so optimistic!". The phrase 'see who we are' is actually a mirrored moment in Lacan's thesis concerning the mirror stage. Here, the participant sees the other participants as a mirror. She sees a shadow or image she thinks herself and the other self that makes her mistakenly identifies (Fink, 1996).

The contradictory phrase 'not so sure, but optimistic' shows a bias in recognizing the shadow in the mirror. Her desire intertwines between the desire of having and the desire of being. Having her own self makes her look at the shadow of the other (with small 'o') showing her capacity which is not comparable with the other participants, but the desire of being excellent like other participants leads her to see the shadow of the Other (with big 'O') which represses her desire but pleasurable, thus providing a sense of optimism. Lacan claims that this big ' $\mathrm{O}$ ' can serve as jouissance, i.e. pleasures resulting from pain due to joyful repression and always make the subject desires to achieve it (Fink, 1996; Ruti, 2010).

\section{THE DESIRE AND PLEASURE OF THE VIEWERS' SUCCESS}

When watching together with two different informants, Arni, 18 years old and Nanang, 23 years old (names deliberately disguised), the author noticed different responses related to the 'DSC' branded reality show aired on a television station on December 14, 2013. Arni, a teenage girl who was just graduated from high school, enthusiastically supported a female participant and gave spontaneous comments to express her desire. Each time her hero (the Challenger she supported) was able to answer the questions from juries and pass to the next round, she always smiled (happy) even sometimes spontaneously applauded.

"If she wins and gets IDR 500 million, how happy she is. ...she must stop being a migrant worker and can venture in her village, no longer worry being tortured or raped by her employer, oh ... fortunately, she is eligible to step in the final so she may get the business capital" (Arni, 18).

Arni, commenting and supporting the Challenger Diah Lestari, a participant whose background is TKW (Indonesian women migrant worker) in Singapore identified her as a housekeeper, whereas Diah Lestari was a chef assistant in a French restaurant in Singapore. Collective discourse (Saukko, 2003) or social discourse (Ruddock, 2001) which is supported by media discourse (Alasuutari, 1999) concerning TKW which is identical to housekeeper greatly affects Arni's personal discourse. Not only 
that, Arni also directly correlates herself with the participant she supports, forms certain imaginations that reflect a desire (of herself and the participant) which is repressed by social discursive reality and media discourse concerning the 'fate' of a TKW. Arni expresses her sympathy and empathy for the TKW to support her success.

In addition, Arnis's desire, mediated by the program, intertwines with identical desire of the TKW participant in achieving success. Arni is a teenage girl who just graduated from high school with a collective/social discourse on her head that affects personal discourse regarding her future success. Arni lives in the openness era of information technology and social media which leads her to learn that success is not present in a single discourse, but live in a plural phrase that makes a teenager like her has many options and opportunities for success including through entrepreneurship. She imagines the pleasure of business success that liberates someone from torment and reflects it on the visual imagination of the participant she supports.

At this point, Arni is embracing her longing for the big ' $\mathrm{O}$ ' which is pleasing and liberating as a form of desire repression under her unconsciousness (Miel, 1966; Ragland, 2000), while the small ' $\mathrm{o}$ ', which is her self-identification mirror (Kirshner 2005; Billig, 2006), she finds in the participant she supports to obtain a capital of IDR 500 million as a way to realize her desire for success pleasure. It is apparently, however, not enough. Her longing for other big ' $\mathrm{O}$ ' which is an ideal system (in the Freudian perspective is represented by a patron figure of father) is other desire that is repressed under her unconsciousness.

"The government should be like this... giving capital for people so that they don't go everywhere looking for jobs like being a maid... especially for women ... that's the proof, they can be creative once given a chance... aaaarghh... the government just thinks about corruption, not the people!" (Arni, 18).

Arni feels the pleasure of success beyond visual imagination she deals with. This is called pleasure in expectation (W.R., 1835). By imagining her expectation of socio-political system which prospers the marginalized people (women), Arni feels the desire and pleasure of the other success. She expects success in a larger context, i.e. success which comes from the government as policy-maker. According to Lacan, such a utopian pleasure will continue to repress the desire and create a joyful pain for the subject. It is jouissance, a peak pleasure that is always pursued by desire but will never be attained, whereas this nonattainment creates joyful pain due to repression of the desire (Fink, 1996).

Another informant, Nanang, a young male adult, last-semester college student, showed his support for a young male participant from Sukoharjo, Central Java. Nanang identified himself with the participant: young, vigorous, relaxed, confident, straightforward, creative and very professional.

"I'm sure he'll win. I can see that he deserves to be a successful person. The way he answers, his spirit, and his experience make me say so ... he must be the winner!" (Nanang, 23)

Nanang focuses on the 'success criteria' of the participant. The criteria are the reflection of his desire that is repressed under his unconsciousness. When visual image produces a sense of 'reality' stimuli in sight, the desire appears and follows the reality. This is a phase that Lacan identifies as the mirror stage (Vasseleu, 1991) which, in the Freudian perspective, is the phase when a symbol of mother figure or the other object with small 'o' (la petit a) according to Lacan, has an important role (Kirshner, 2005). It is the mirror where the subject either sees himself and his own identity, or, becomes himself (Ruti, 2010).

Nanang is a last-semester student who will immediately enter the professional world. His desire for success is of course so great. When saying 'he must be the winner', he is actually sparking his confidence by reflecting success (of participants over himself) upon the image of an exciting future. This imagination of success gives 
pleasure (Feagin, 1984), thus pushing his desire to make it happen immediately, while the pleasure itself is produced from the sensation of textual visuality of sensory imagination (Shusterman, 1982).

For Nanang, therefore, the victory of the participant he supports is a form of pleasure that is born from desire repressed and stored in his unconsciousness, the desire to win (small 'o'), self-identification desire that appears in the visual image object he watches. However, this pleasure produces another desire that makes him feel a sense of lack. This desire is the desire of being a successful person because, here, there is pleasure (big 'O') which also serves as the ideal ego of the self or the subject.

According to Lacan, this ideal ego or the Real will never be really achieved because, existentially, humans are actually controlled by different senses of loss and lack, while the lack, in such an existential meaning, will certainly never be full or be met (in the attempt to get the Real which is the early phase of human life when the subject has not yet recognized the otherness) (Vasseleu, 1991).

Nanang's utopian phrase 'deserve to be a successful person' is an expression of longing for the big ' $\mathrm{O}$ ' or the object of desire that produces jouissance (Ott, 2004), the climax of pleasure resulting from the repressive pain suffered by the desire in pursuit of the big ' $\mathrm{O}$ ' or ideal ego or 'the Real' which actually always produces an endless sense of lack. Thus, Nanang's small 'o' is pleasure from the desire of having victory while his big ' $\mathrm{O}$ ' is pleasure from the desire of being a successful person through visual images of the participant he supports and watches. Someday, Nanang might really get such a success, but the standard of the success will continue to change, so that he would always feel a sense of lack (read: not successful yet), and would keep also pursuing his big ' $O$ '. This is what Lacan claims as the impossibility to reach the Real big ' $O$ '. The humans never stop desiring it (since it is pleasurable), although they are always exposed to a sense of lack that keeps repressing it.

What about the desire and pleasure of brand? Some moments were noticed when brand appeared in the show. First, when the brand flashed out in the segment turnover, both Arni and Nanang did not give any response, but were only glued to the television screen. In addition to its duration which was only a second, this flash-out could also be regarded as an accessory that was not significant enough to distract the viewers' attention.

The response was different when advertising segments appeared. As the sole organizer and sponsor, the entire ad space was monopolized by 'DSC' producer's brand. Arni, holding the television remote spontaneously changed the channel to another station program, while Nanang moved from his place to do other work (taking snacks in another room) and returned a few minutes later, seated while continuing to watch. He immediately reminded Arni to return to the 'DSC' program channel, and Arni immediately changed the channel when the ad duration ended.

"You're not willing to miss it, as if your hero will get the prize!" Arni tempted Nanang.

"Of course, he will! The winner will be soon announced. I'm just curious.."

"So what if you know the winner?" the author tried to provoke.

"Just happy, especially if my hero wins," said Nanang with a happy face. (Excerpt from conversation observation, December 14, 2013).

The desire and pleasure shown by informants only focus on TV show discourse, not at all related to brand, or even product. This phenomenon seems to less support the thesis of La Ferle \& Edwards (2006) and Cornwell, et al., (2006) which states that brand placement and program sponsorship give significant consciousness and articulation in the consumer memory. Is this caused by TV show discourse which is not congruent with the functional brand benefit? Or 
is this phenomenon common these days where the audiences begin to be apathetic towards advertising so that they always switch channel when ads segment appears? Whatever the cause, the branded reality show 'DSC' has managed to divert the brand reality consciousness to the social reality consciousness in correlation to the discourse of success.

\section{CONCLUSION}

Although the branded reality show 'DSC' has revealed the desire and pleasure of success in spectatorship, it never touches the product reality as the main figure behind the TV show program. This branded reality show is made and sponsored by a single tobacco product brand, while smoking is still a controversial issue in the social discourse of Indonesian society. Not only considered harmful to health, smoking is also feared to be addictive especially for children and adolescents.

In this way, unconsciousness structure has 'concealed' consciousness reality about the discourse of tobacco product negativeness. The desire and pleasure of success become a powerful discourse that alienates a negative issue related to such a product. Of course, this is advantageous to the company as the product brand owner. The politics of reality, through a success discourse in branded reality show, successfully penetrates into the subconscious of the society and controls their unconsciousness. As stated by Lacan's thesis where unconsciousness controls the ego, the discourse on success pleasure, which is constructed by the company under unconsciousness and then intertwines with the desire of having success/being successful, leads the consciousness to control (read:buy) the product as an ego or body of reality. This is where the discourse and illusion of success reality which is constructed by the company serve as an unconsciousness tunnel (of desire and pleasure) towards consciousness (of buying the product or having positive perception towards the brand), and the branded reality show 'DSC' is the vehicle.
Another interesting finding in this study is that the viewers/audiences consider the branded reality show 'DSC' as a mirrored vehicle to see the desire and pleasure of their own success through the participants. There are two assumptions that can be made with regard to how viewers respond to the discourse and identify themselves with subjects in the spectacle (show). Firstly, there is an emphatic and figural tendency, in the sense that the audiences/viewers really focus on and are glued to the participants they support based on a high sense of empathy (related to the background of the participant who is a migrant worker). Secondly, there is a logic and systematical tendency, in the sense that the audiences/viewers focus on the capacity and quality of participants they support based on a structured and rational analysis. However, whatever their response style is, the viewers/audiences cannot escape from the unconscious panorama revealing their desire and pleasure of success through the language of visual images of the participants they mirror. Lacan claims that the desire of the subject and the other in the mirror cannot be distinguished, so that the subject often mistakenly identifies: the other is considered his/her self, while his/her self is considered the other. This is the reality of otherness in Lacan's perspective that serves as a pleasurable object for the subject.

Although there is weakness in comprehensively studying branded reality show in Indonesia due to lack of data and literature, this study can be a 'gate' to further investigate the phenomena of branded reality show in Indonesia (as well as other countries) especially from the perspective of psychoanalysis. Considering the limited literature in this field of study, the results of this study may be a useful reference for subsequent researches. At least, there are some interesting points to be further observed. Firstly, branded reality show may be used by a brand as a medium of politics of reality, i.e. the construction of reality through a particular discourse to avoid another constructive reality repression. Secondly, 
psychoanalysis can reach both spectacle (show), spectator (viewers), and spectatorship as the object and subject of reality show studies, or borrowing the Metz's phrase: reality show spectatorship. Thirdly, psychoanalysis can unravel the subject unconscious narration which serves as the study object in the control of consciousness, so that the desire and pleasure of the subject can be read through the reality that appears in the reality show text or discourse.

Notes:

1 This term is used by Rossie Baker for her article, "Reality Bites: Kellogg's Adds Extra Iron to Branded TV Show" in AdNews, October 10, 2013. Retrieved on January 20, 2014, from http://www.adnews.com.au/ adnews/reality-bites-kellogg-s-adds-extrairon-to-branded-tv-show

\section{REFERENCES}

Adi, I. R. (2006). "A Symbolic Reality of American Television: A Case Study of the Jerry Springer Show". Jurnal Humaniora, Vol. 18, No. 2, 191199.

Alasuutari, P. (1999). "Introduction: Three Phases of Reception Studies" in P. Alasuutari (ed), Rethinking the Media Audience: the New Agenda, 1-21. London: Sage Pub.

Alcorn, M. W. (1994). "The Subject of Discourse: Reading Lacan through (and Beyond) Poststructuralist Contexts" in M. Bracher, M. W. Alcorn, Jr., R. J. Corthell \& F. Massardier-Kenney (eds). Lacanian Theory of Discourse: Subject, Structure, and Society. NY: New York University Press.

Aslama, M. \& Pantti, M. (2006). "Talking Alone: Reality TV, Emotions and Authenticity". European Journal of Cultural Studies, Vol. 9, No. 2, 167-184.

Bennett, W. L. (2005). "News as Reality TV: Election Coverage and the Democratization of Truth". Critical Studies in Media Communication, Vol. 22, No. 2, 171-177.
Billig, M. (2006). "Lacan's Misuse of Psychology: Evidence, Rhetoric and the Mirror Stage". Theory Culture Society, Vol. 23, No. 4, 1-26.

Bonsu, S. K., A. Darmody \& M. A. Parmentier. (2010). "Arrested Emotions in Reality Television". Consumption Markets \& Culture, Vol. 13, No. 1, 91-107.

Bourdieu, P. (2001). "Television”. European Review, Vol. 9, No. 3, 245-256.

Brioux, B. (2008). Truth and Rumors: The Reality behind TV's Most Famous Myths. USA: Praeger.

Coles, G. (2000). "Docusoap: Actuality and the Serial Format" in B. Carson \& M. Llewellyn-Jones (eds), Frames and Fictions on Television: The Politics of Identity in Drama, 27-39. Exeter: Intellect.

Cornwell, T. B., M. S. Humphreys, A. M. Maguire, C. S. Weeks \& C. L. Tellegen. (2006). "SponsorshipLinked Marketing: The Role of Articulation in Memory". Journal of Consumer Research, Vol. 33, No. 3, 312-321.

Deery, J. (2004). "Reality TV as Advertainment". Popular Communication: The International Journal of Media and Culture, Vol. 2, No. 1, 1-20.

Feagin, S. L. (1984). "Some Pleasures of Imagination". The Journal of Aesthetics and Art Criticism, Vol. 43, No. 1, 41-55.

Fink, B. (1996). The Lacanian Subject, Between Language and Jouissance. USA: Princeton University Press.

Flitterman-Lewis, S. (2005). "Psychoanalysis, Film, and Television" in R. C. Allen (ed), Channels of Discourse, Reassembled: Television and Contemporary Criticism, 152-185. UK: Routledge.

Grassl, W. (1999). "The Reality of Brands: Towards An Ontology of Marketing". American Journal of Economics and Sociology, Vol. 58, No. 2, 313359.

Hill, A. (2005). Reality TV: Audiences and Popular Factual Television. Oxon: Routledge.

Kirshner, L. A. (2005). "Rethinking Desire: The Objet Petit A in Lacanian Theory". Journal of the American Association Psychoanalytic, Vol. 53, No. 1, 83-102. 
Kjus, Y. (2009). "Idolizing and Monetizing the Public: The Production of Celebrities and Fans, Representatives and Citizens in Reality TV". International Journal of Communication, Vol. 3, 277-300.

Komberger, M. (2010). Brand Society, How Brands Transform Management and Lifestyle. Cambridge, UK: Cambridge University Press.

La Ferle, C. \& Edwards, S. M. (2006). "Product Placement: How Brands Appear on Television". Journal of Advertising, Vol. 35, No. 4, 65-86.

Lacan, J (1997). The Language of the Self: The Function of Language in Psychoanalysis. Translated by Anthoni Wilden. USA: John Hopkins University Press.

(2006). Ecrits (the first complete edition in English). Translated by Bruce Fink in collaboration with Heloi'se Fink and Russell Grigg. NY: Norton \& Company.

Lehu, Jean-Marc. (2007). Branded Entertainment: Product Placement and Brand Strategy in the Entertainment Business. USA: Kogan Page.

MetroTV (2013). 'Diplomat Success Challenge' Episode: 1-GF. Retrieved on January 31, 2014, from https://www.youtube.com/watch?v=053 aST_rf8\&noredirect=1

Miel, J. (1966). "Jacques Lacan and the Structure of the Unconscious". Yale French Studies (Structuralism), Vol. 36/37, 104-111.

Nabi, R. L. (2007). "Determining Dimensions of Reality: A Concept Mapping of the Reality TV Landscape". Journal of Broadcasting \& Electronic Media, Vol. 51, No. 2, 371-390.

Ott, B. L. (2004). "(Re)locating Pleasure in Media Studies: Toward an Erotic of Reading". Communication and Critical/Cultural Studies, Vol. 1, No. 2, 194-212.

Papacharissi, Z. \& A. L. Mendelson (2007). "An Exploratory Study of Reality Appeal: Uses and Gratifications of Reality TV Shows". Journal of Broadcasting \& Electronic Media, Vol. 51, No. 2, 355-370.

Ragland, E. (2000). "Dreams According to Lacan's re-interpretation of the Freudian Unconscious". Parallax, Vol. 6, No. 3, 63-81.

Reiss, S. \& J. Wiltz (2004). "Why People Watch Reality TV". Media Psychology, Vol. 6, No. 4, 363-378.

Ruddock, A. (2001). Understanding Audiences: Theory and Method. London: Sage Pub.

Russell, C. A. (2007). Advertainment: Fusing Advertising and Entertainment. USA: Yaffee Center for Persuasive Communication University of Michigan.

Ruti, M. (2010). "The Singularity of Being: Lacan and the Immortal Within". Journal of the American Association Psychoanalytic, Vol. 58, No. 6, 11131138.

Saukko, P. (2003). Doing Research in Cultural Studies: An Introduction to Classical and New Methodological Approaches. London: Sage Pub.

Shusterman, R. (1982). "Aesthetic Blindness to Textual Visuality". Journal of Aesthetics and Art Criticism, Vol. XLI, No. 1, 88.

Vasseleu, C. (1991). "The Face before the MirrorStage”. Hypatia, Vol. 6, No. 3, 140-155.

W. R. (1835). "The Pleasures of Hope". The Dublin Penny Journal, Vol. 4, No. 177, 163-164.

Wijaya, B. S. (2011). "Model Komunikasi Berasa dalam Komunikasi Pemasaran: Studi mengenai Iklan Ambient Media dalam Meraih Kepercayaan Khalayak Konsumen". Journal Communication Spectrum, Vol. 1, No. 1, 55-74.

. (2013). "Dimensions of Brand Image: A Conceptual Review from the Perspective of Brand Communication". European Journal of Business and Management, Vol. 5, No. 31, 55-65.

Winston, B. (1995). Claiming the Real: The Documentary Film Revisited, London: British Film Institute.

Wismilak-diplomat (2013). About the Competition. Wismilak-diplomat.com. Retrieved on January 20, 2014, from http://www.wismilak-diplomat.com/ dsc2013/content/about-the-competition/

Zizek, S. (1997). The Plague of Fantasies. NY: Verso. 